\title{
Российские квантовые каскадные лазеры ТГц диапазона
}

\author{
В.И. Гавриленко ${ }^{1}$, Р.А. Хабибуллин ${ }^{2}$ \\ ${ }^{1}$ Институт физики микроструктур РАН, Нижний Новгород, 603087, Академическая, 7 \\ ${ }^{2}$ Институт сверхвысокочастотной полупроводниковой электроники имени В.Г. Мокерова РАН, \\ Москва, 117105, Нагорный проезд, 7, стр.5 \\ тел:+7 (831) 417-9462, факс:+7 (831) 417-9474, эл.nочта: gavr@ipmras.ru
}

DOI 10.34077/RCSP2021-17

Как известно, идея создания источника излучения, основанного на последовательном испускании фотонов электроном в структуре множественных квантовых ям, получившего впоследствии название квантового каскадного лазера (ККЛ), была высказана в СССР еще в 1971 г. [1], однако потребовалось более 20 лет для реализации первого ККЛ, работающего в среднем ИК диапазоне [2]. Первый ККЛ ТГц диапазона был представлен в 2002 г. в совместной работе нескольких европейских групп [3]. Различные российские группы благодаря сотрудничеству с зарубежными коллегами участвовали в исследовании ТГц ККЛ и развивали методики их практических приложений. Первый полностью российский ТГц ККЛ был продемонстрирован лишь в 2017 г. в совместной работе научных коллективов из Санкт-Петербурга, Москвы и Н.Новгорода [4]. В докладе буден сделан обзор прогресса в конструировании, выращивании, постростовых технологиях и исследованиях ТГц ККЛ, проводимых консорциумом российских организаций в сотрудничестве $\mathrm{c}$ коллегами из Белорусского госуниверситета. Разработана модель расчета вольт-амперных и мощностных характеристик ККЛ ТГц диапазона, учитывающая эффекты дефазировки на процессы переноса носителей заряда [5]. Применительно к установке молекулярно-пучковой эпитаксии (МПЭ) Riber 21 отработана технология роста структур с квантовыми ямами GaAs/AlGaAs для ТГц ККЛ с учетом изменения температур источников галлия и алюминия в процессе длительного ( 10 час.) роста образцов с толщинами активных областей около 10 мкм. Высокое кристаллическое качество структур подтверждено методами рентгеноструктурного анализа и просвечивающей электронной микроскопии [6]. Исследованы спектры модовых потерь в ТГц ККЛ с волноводами типа металл-металл на основе Аu, $\mathrm{Cu}$ и $\mathrm{Ag}$. Показано, что использование волновода на основе $\mathrm{Ag}$ позволяет снизить потери на 2-4 см${ }^{-1}$ по сравнению с традиционно используемым волноводом на основе Аu $[7,8]$. Оптимизирован дизайн ККЛ с 3 квантовыми ямами $\mathrm{GaAs} / \mathrm{Al}_{0.15} \mathrm{Ga}_{0.85} \mathrm{As}$ в каскаде с депопуляцией нижнего лазерного уровня за счет резонансного испускания оптических фононов с расчетной рабочей температурой свыше $200 \mathrm{~K}$. Выращена и спроцессирована структура такого ККЛ, продемонстрировавшая генерацию на частоте 3.4 ТГц с максимальной рабочей температурой (в импульсном режиме) свыше $130 \mathrm{~K}$ [6]. Разработан дизайн активной области ТГц ККЛ (3 ТГц) с двумя квантовыми ямами $\mathrm{GaAs} / \mathrm{Al}_{0.4} \mathrm{Ga}_{0.6} \mathrm{As}$ в каскаде c Zобразным профилем потенциала с максимальной расчетной рабочей температурой $300 \mathrm{~K}$.

\section{Лumepamypa}

[1] Р.Ф. Казаринов, Р.А. Сурис. // ФТП. 1971. Т.5, вып.4. С.797-800.

[2] J. Faist et al. // Science. 1994. V.264. P.553-556.

[3] R. Koehler et al. // Nature. 2002. V.417. P.156-159.

[4] А.В. Иконников и др. // Письма в ЖТФ. 2017. Т.43, вып.7. С.86-94.

[5] Д.В.Ушаков и др. // Квантовая электроника. 2019. Т.49, вып.10. С.913-918.

[6] I.S. Vasilevskii et al. The 4th Int. Conf. Terahertz and Microwave Radiation: Generation, Detection, and Applications ("TERA 2020"). August 24-26, 2020 Tomsk, Russia. Abstracts, p.31.

[7] R. Khabibullin et al. // Proc. SPIE. 2019. V.11022. P.1102204-(1-8).

[8] R. Khabibullin et al. // Proc. SPIE. 2019. V.11066. P.1106613-(1-6). 